\title{
Age, sex, location ... sperm count?
}

$\mathrm{T}$ rent Arsenault's website could easily be mistaken for an online dating profile. There, the 36-year-old Silicon Valley hightech worker describes his appearance (blond hair, brown eyes), personality ("happy, easy going") and hobbies ("hiking, bird watching, habitat conservation").

But interspersed among action shots of Arsenault biking in China and scuba diving in Hawaii are snapshots of his sexual health records, genetic testing results and the 15 children he's fathered since hanging up a shingle in 2006 as a "free sperm donor" (http ://trentdonor.org).

He's part of a burgeoning online network of willing donors and wouldbe mothers who are bypassing the anonymity and expense of licensed sperm banks in favour of a more do-ityourself approach to assisted conception, much to the ire of semen regulators who have decried the practice as a threat to public health.

Arsenault has been locked in a regulatory battle with the United States Food and Drug Administration (FDA) since 2010, when the regulator ordered him to stop making private donations unless he could meet the stringent requirements it has set out for sperm banks.

"On that logic, every man in America could be a risk to their partner," Arsenault contends. Indeed, he claims to pose a reduced risk in comparson with men who beget children the oldfashioned way because he's celibate, provides documentation of regular screening for sexually transmitted infections and donates via a sterile cup and syringe.

Now, Canadian proponents of free sperm donation fear the case will set a precedent for similar crackdowns by Health Canada, which has already issued two alerts about the "serious potential health risks" of the practice (www.hc -sc.gc.ca/ahc-asc/media/advisories-avis /_2010/2010_218-eng.php and www.hc

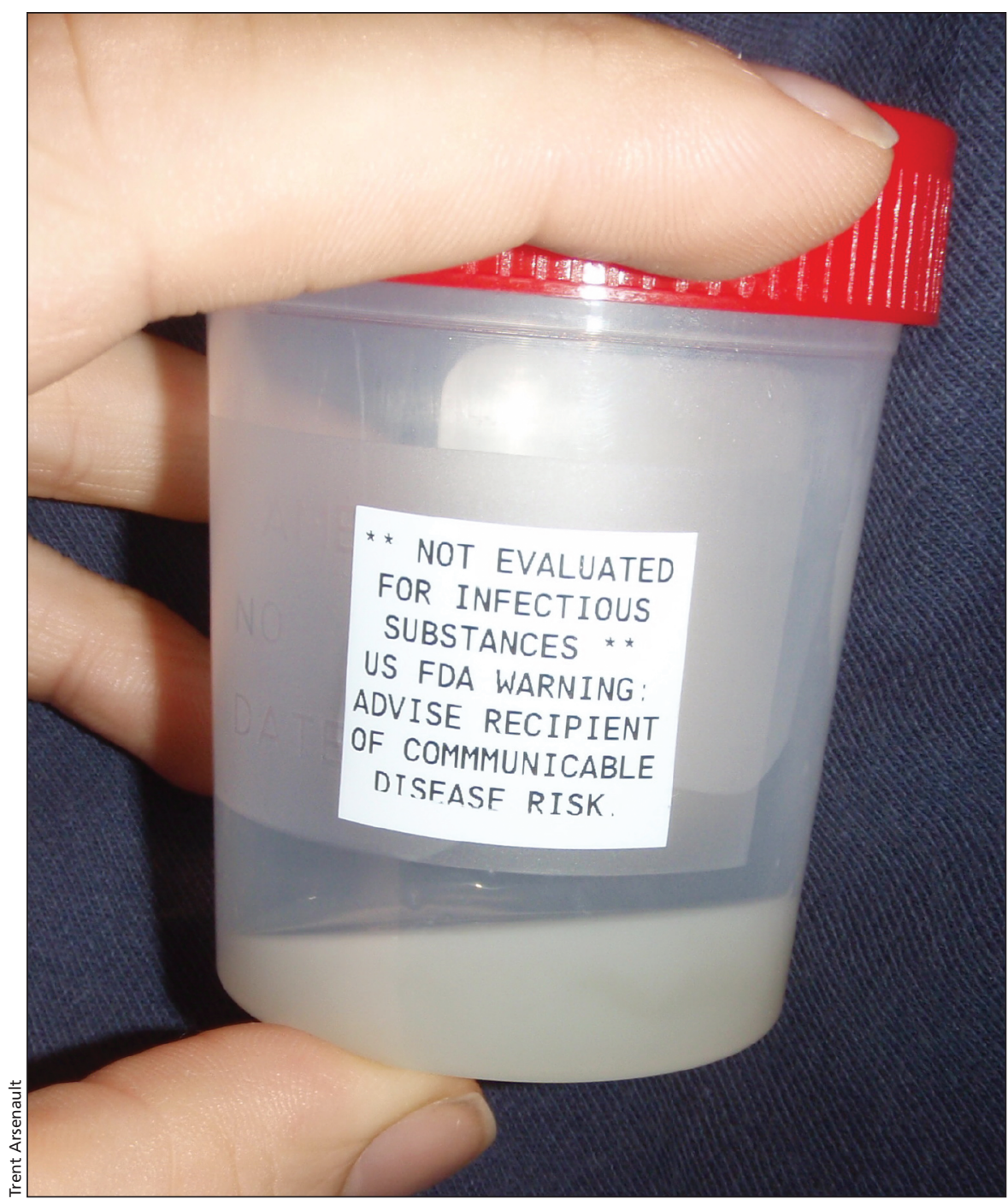

Trent Arsenault provides his donated sperm via a sterile cup.

-sc.gc.ca/ahc-asc/media/advisories-avis /_2011/2011_116-eng.php).

"I'm absolutely concerned," says Sam [who requested her last name be withheld], a Toronto, Ontario-based mother who is attempting to conceive a second child using free donations from men she's met online. She and her partner spent more than $\$ 10000$ conceiving their first child via a licensed sperm bank. "We go into it with our eyes wide open, know what our risks are and make the decision based on the information we're provided and what our guts tell us. Ultimately, it's no worse than going to a bar and picking someone up."

But it's the fact that private donors and recipients are not having sex that's exposing them to scrutiny from regulators in Canada, the United Kingdom and the US.

Semen is regulated as a drug in Canada, unless it's donated to a spouse or sexual partner, according to Leslie Meerburg, a media relations officer for Health Canada. As a drug, it must pass through a battery of checks under the Food and Drugs Act and "Processing and Distribution of Semen for Assisted 
Conception Regulations," including a six-month quarantine period during which the sperm is frozen.

This effectively makes it impossible for individuals to donate fresh sperm privately without having sex or breaking the law, says Emily Larose, a Toronto, Ontario-based lawyer who specializes in dealing with health regulations.

Private donors who opt to do the latter could face compliance and enforcement actions, including prosecution, although "the extent to which Health Canada would take these enforcement measures is not certain," Larose says. "I don't know whether a friend helping out a friend would be a situation that would trigger this kind of scrutiny, [but] when people are doing it in a broader, more public sense [as they are online] they attract the regulator's attention."

That's been the case in both the UK and the US, where similar restrictions on semen donation and exemptions for donations from "intimate" partners apply (www.legislation.gov.uk/uksi/2007/1522 /pdfs/uksi_20071522_en.pdf and www .fda.gov/BiologicsBloodVaccines/Tissue TissueProducts/QuestionsaboutTissues /ucm102842.htm). In recent years, the UK's Human Fertilisation and Embryology Authority has given written notice to private sperm donation sites to warn that their unlicensed operation constitutes a criminal offence (www.hfea.gov.uk /1369.html).

But Arsenault's case appears to be the first in which a regulator has targeted an individual donor for enforcement. He had already sired 10 children via artificial insemination and made some 328 donations to 46 different recipients when FDA investigators searched his home in August 2010. Three months later, he received the order to "cease manufacturing" donations there unless he could "provide adequate protections against the risk of communicable disease transmission" (http://trentdonor.org/v/logos /fda_inspection/fda_order_to_cease_man ufacturing_01-nov-2010/FDA-order-to -cease-manufacturing-trentdonor-01-Nov -2010-pg-1of5.jpg.html).

Advocates for free sperm donation argue it's unfair to hold individuals to the same standards as sperm banks, particularly as many private donors disclose more information about their sexual health, genetics and fertility than most people require of their so-called intimate partners.

Adam [who requested his last name be withheld], a Saskatoon, Saskatchewan-based student, writes in an email that he's taken greater precautions in preparing to become a private donor than even most recipients require. In addition to screening for sexually transmitted infections, he has undergone genetic testing, conferred with a lawyer about his responsibilities to recipients and any resulting children, and sought to determine whether there is a maximum number of children a donor may have per population. And like Arsenault, Adam abstains from sex.

Although Adam acknowledges that not all donors go to such lengths either because of ignorance or "darker motives" - he accuses government of overreaching its authority by extending their hand into the bedrooms of private citizens. "There needs to be protection in place [for] both the parties. Having said that, ... this comes down to the old argument of the government trying to restrict what consenting adults want to do."

Others contend the regulations force women to choose between the financial consequences of using a sperm bank and the physical and emotional risks of having sex with a stranger.

"That's a crappy choice, and guess what? That person still wants to have a baby and they're going to find a way," says Beth Gardner, founder of the USbased Known Donor Registry, a site that currently connects some 5750 people interested in private donation, including Canadians. "It's not the realm of government to decide who I'm allowed to have a baby with and how I'm going to make that happen. That's my business."

Current restrictions only serve to force such transactions underground, putting desperate women at a greater risk of being coerced into sex or obtaining sperm from unscrupulous donors who have foregone screening, Gardner adds.

A "much more appropriate" alterna- tive to imposing one-size-fits-all regulations on sperm banks and individual donors alike would be to create a distinct set of guidelines on how to engage in private donation as safely as possible, she argues. That could be as simple as recognizing private donor-recipient relationships as "intimate" and therefore exempt from the regulations governing sperm donations, or the development of some form of universal checklist or consent form that sets out each party's risks and responsibilities.

Erika Tranfield, director and cofounder of the UK-based private donation site Pride Angel, concurs. A less restrictive approach would also enable women and donors to work more closely with health professionals to carry out private donations, ensuring an additional layer of accountability while retaining the ability to "create their own rules," she says.

Many women are attracted to private donation because it allows them to meet potential sperm donors in person, and screen for personality and other characteristics that are difficult to judge from sperm bank profiles, Tranfield says. The parties can also customize the level of contact they propose to maintain after a child is conceived, she adds. "It eliminates the longing to meet the donor when they're older and the child is obviously able to say 'I have a dad,' making them no different from the kids at school."

Arsenault has kept in touch with several of the families which were recipients of his sperm and those relationships are the basis on which he's appealing the FDA kibosh on his activities as donor.

"The recipients and I agree we're intimate partners," Arsenault says, adding that the FDA doesn't have a right to define what constitutes sexual intimacy for individuals.

The FDA hasn't yet indicated whether it will grant a hearing on his appeal but in the mean time, Arsenault says he'll continue donating.

The FDA did not respond to requests for an interview. - Lauren Vogel, CMAJ

CMAJ 2012. DOI:10.1503/cmaj.109-4156 